\title{
A Novel Therapeutic Strategy for the Treatment of Glioma, Combining Chemical and Molecular Targeting of Hsp90 $\alpha$
}

\author{
Adi Mehta, Leroy Shervington, Chinmay Munje and Amal Shervington *
}

Brain Tumour North West, Faculty of Science and Technology, University of Central Lancashire, Preston, PR12HE, UK; E-Mails: abmehta@uclan.ac.uk (A.M.); lashervington@uclan.ac.uk (L.S.); crmunje@uclan.ac.uk (C.M.)

* Author to whom correspondence should be addressed; E-Mail: aashervington@googlemail.com; Tel.: +44-0-1772893519; Fax: +44-0-1772892929.

Received: 21 October 2011; in revised form: 21 November 2011 / Accepted: 30 November 2011 / Published: 8 December 2011

\begin{abstract}
Hsp90a's vital role in tumour survival and progression, together with its highly inducible expression profile in gliomas and its absence in normal tissue and cell lines validates it as a therapeutic target for glioma. Hsp90 $\alpha$ was downregulated using the post-transcriptional RNAi strategy $(\operatorname{sihsp} 90 \alpha)$ and a post-translational inhibitor, the benzoquinone antibiotic 17-AAG. Glioblastoma U87-MG and normal human astrocyte

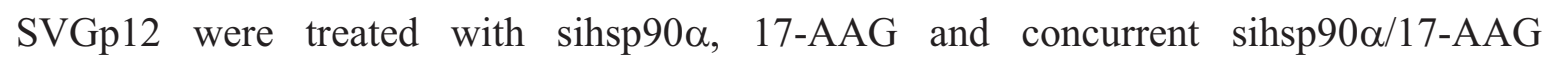
(combined treatment). Both Hsp90 $\alpha$ gene silencing and the protein inhibitor approaches resulted in a dramatic reduction in cell viability. Results showed that sihsp90 $\alpha, 17-\mathrm{AAG}$ and a combination of sihsp $90 \alpha / 17-\mathrm{AAG}$, reduced cell viability by $27 \%, 75 \%$ and $88 \%$ ( $\mathrm{p}<0.001$ ), respectively, after 72 h. hsp $90 \alpha$ mRNA copy numbers were downregulated by $65 \%, 90 \%$ and $99 \%$ after $72 \mathrm{~h}$ treatment with sihsp $90 \alpha, 17-\mathrm{AAG}$ and sihsp $90 \alpha / 17-\mathrm{AAG}$, respectively. The relationship between Hsp90 $\alpha$ protein expression and its client Akt kinase activity levels were monitored following treatment with sihsp90o, 17-AAG and sihsp90 $\alpha / 17-A A G$. Akt kinase activity was downregulated as a direct consequence of Hsp90 $\alpha$ inhibition. Both Hsp90 $\alpha$ and Akt kinase levels were significantly downregulated after $72 \mathrm{~h}$. Although, 17-AAG when used as a single agent reduces the Hsp90 $\alpha$ protein and the Akt kinase levels, the efficacy demonstrated by combinatorial treatment was found to be far more effective. Combination treatment reduced the Hsp90 $\alpha$ protein and Akt kinase levels to $4.3 \%$ and $43 \%$, respectively, after $72 \mathrm{~h}$. hsp $90 \alpha$ mRNA expression detected in SVGp12 was negligible compared to U87-MG, also, the combination treatment did not
\end{abstract}


compromise the normal cell viability. Taking into account the role of Hsp90 $\alpha$ in tumour progression and the involvement of Akt kinase in cell signalling and the anti-apoptotic pathways in tumours, this double targets treatment infers a novel therapeutic strategy.

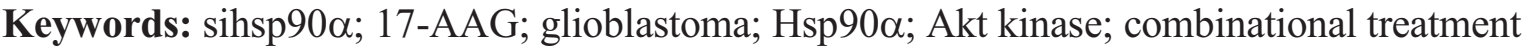

\section{Introduction}

Glioblastoma multiforme (GBM) is the most common malignant form of glioma, accounting for approximately $60-70 \%$ of all glioma cases and characterised by metastatic growth, malicious invasion and poor prognosis [1,2]. The current treatment for GBM consists of surgical removal of the tumour, followed by radiotherapy and concomitant use of the chemotherapeutic alkylating drug temozolomide (as recommended by The National Institute of Health and Clinical Excellence), which confers a survival period of 12-15 months [3]. Due to the modest effects of conventional treatment therapies, there is an urgent need for more effective ones.

The molecular chaperone heat shock protein 90 (Hsp90) has recently emerged as a vital target for cancer therapy. Hsp90 accounts for $1-2 \%$ of total protein in normal cells, which under stress conditions increases to $4-6 \%[4,5]$. Hsp90 is upregulated in various human tumours where stress is prevalent, which may reflect the ability of malignant cells to maintain homeostasis in noxious environments [6,7]. Hsp90 binds to an array of client proteins, many of which are involved in apoptosis, cell survival and growth pathways [8]. Many of these client proteins are mutated or overexpressed in GBM [1] and therefore, inhibiting Hsp90 protein or its inducible component Hsp90 $\alpha$, could disrupt the oncogenic signalling pathways. Hsp90 silencing can be achieved using the benzoquinone antibiotic 17-allylamino-17-demethoxygeldanamycin (17-AAG) which is an Hsp90 inhibitor [9] and RNA interference (RNAi) using small interfering RNA (siRNA) [10].

17-AAG promotes growth inhibition in a number of cell lines, including gliomas, as well as antitumour activity in vivo and in preclinical models [11-15]. 17-AAG binds to the $N$-terminal domain of Hsp90 consequently inducing proteasomal degradation of its client proteins [16-18]. The combinatorial effect of 17-AAG on multiple signal transduction pathways involved in proliferation and survival, makes 17-AAG an ideal candidate for cancer therapy in GBM whose etiology is diverse. Moreover, the lipophilic nature of this drug allows easy access through blood brain barrier [1], and thus has a potential therapeutic value in GBM.

In humans, there are two major isoforms of Hsp90, namely Hsp90 $\alpha$ and Hsp90 $\beta$ [19]. Although, Hsp90 $\alpha$ levels in normal cells is lower compared to Hsp90 [19], Hsp90 $\alpha$ expression is highly inducible to stressful stimuli such as heat shock, alcohol, heavy metals, oxidative stress and osmotic pressure changes, predominant in tumours [20]. In contrast, Hsp90 $\beta$ is thought to be constitutively expressed [21]. The high expression levels of Hsp90 $\alpha$ has been associated with tumour progression, enhanced cell cycle regulation and induced cell signalling via tyrosine kinases [22]. A previous study in our laboratory showed high levels of both Hsp90 $\alpha$ mRNA and protein expression in glioma cell lines and tissues in contrast to normal counterparts [23]. Therefore, silencing $h s p 90 \alpha$ can be a potential treatment strategy for GBM. The RNAi potential in gene therapy has been confirmed by several 
preclinical studies performed in the treatment of mammalian tumours [24-26]. siRNAs have emerged as an effective therapeutic strategy to silence disease genes, whereby it interferes with the translation of almost any mRNA [27]. Recently, we showed that three siRNA constructs target-specific to the human $h s p 90 \alpha$ gene significantly reduced $h s p 90 \alpha$ expression after $48 \mathrm{~h}$ [28]. Furthermore, the glioma cell lines treated with a combination of TMZ and siRNA, showed enhanced chemosensitivity to TMZ by a 13-fold reduction in the concentration of TMZ required in order to achieve the same cytotoxic effects as TMZ alone [28].

Clinical studies to date have shown only modest activity with molecular agents directed at single targets, due to coactivation of multiple tyrosine kinases and the presence of redundant signalling pathways [29]. Given the ability of 17-AAG to target several signalling pathways in GBM, we assessed its effects on tumour growth and survival, both as a single agent and in combination with siRNA (sihsp90 $\alpha$ ). This investigation aimed at downregulating Hsp90 $\alpha$ mRNA and protein levels utilizing 17-AAG, siRNA and a combination of 17-AAG/sihsp90 $\alpha$. The efficacy and the ability of siRNA to synergise with $17-\mathrm{AAG}$ and inhibit tumour growth was determined by measuring gene expression and protein levels. The Akt kinase protein activity, a client protein of Hsp90 widely known for its involvement in anti-apoptotic pathway [1], was also monitored.

\section{Results and Discussion}

\subsection{Combinatorial Assays with 17-AAG and sihsp90 $\alpha$ Inhibits Tumour Growth in U87-MG but Does not Affect SVGp12 Cell Viability}

To determine the cell viability, U87-MG and SVGp12 cells were treated with 17-AAG and sihsp $90 \alpha$ simultaneously with concurrent combinatorial assay. Both the gene silencing and protein inhibitor approaches showed dramatic reduction in cell viability in U87-MG (Figure 1A). Data showed that sihsp $90 \alpha, 17-A A G$ and combination of sihsp $90 \alpha / 17-A A G$ reduced cell viability by $27 \%, 75 \%$ and $88 \%$ after $72 \mathrm{~h}$, respectively. Cytotoxic effects of 17-AAG, as a single agent, far exceeded the cytotoxic effects shown by sihsp90 $\alpha$ at either 48 or 72 h. 17-AAG restricted tumour growth to $51 \%$ and $25 \%$ and sihsp90 $\alpha$ treatment impaired tumour growth to $89 \%$ and $73 \%$ after $48 \mathrm{~h}$ and $72 \mathrm{~h}$, respectively. To determine the therapeutic potential of this combination treatment, normal astrocyte cell line SVGp12 was treated with sihsp90 $\alpha$ and 17-AAG for $48 \mathrm{~h}$ and $72 \mathrm{~h}$ (Figure 1B). Neither treatments significantly reduced SVGp12 cell viability after $48 \mathrm{~h}$ or $72 \mathrm{~h}$ thus demonstrating the tumour-specific targeting of this combination treatment.

\section{2. sihsp90 $\alpha$ Synergize with 17-AAG Treatment in U87-MG Cell Line}

The ability of sihsp90 $\alpha$ to synergize with $17-$ AAG in U87-MG was examined. The efficacy of the concurrent assay with 17-AAG and sihsp $90 \alpha$ was assessed using interaction ratios generated by a ratio of the observed growth inhibition following treatment with both compounds versus growth inhibition using either compound independently. A ratio of 1 indicates additive growth inhibition, a ratio greater than 1 demonstrates synergistic growth inhibition, while a ratio less than 1 suggests subadditive effects on growth inhibition [1]. The interaction ratio calculated for concurrent treatments in this study is listed in Table 1. The results indicate that sihsp90 $\alpha$ can synergize with 17-AAG and enhance treatment 
efficacy in glioblastoma. Upon statistical analysis, the concurrent treatment with 17-AAG and sihsp90 $\alpha$ showed significant reduction in cell viability after $48 \mathrm{~h}$ and $72 \mathrm{~h}$ as compared to either treatment acting individually.

Figure 1. 17-AAG and sihsp90 $\alpha$ effect on cell viability in vitro. Cell viability was monitored for cells treated with 17-AAG and sihsp90 $\alpha$ after $48 \mathrm{~h}$ and $72 \mathrm{~h}$ in (A) U87-MG and (B) SVGp12. Control represent untreated cells, sihsp90 $\alpha$ represent cells treated with hsp $90 \alpha$ specific siRNA. sihsp90 $\alpha+17-\mathrm{AAG}$ represents concurrent assays where the cells were treated with $17-\mathrm{AAG}$ and sihsp $90 \alpha$ for either $48 \mathrm{~h}$ or $72 \mathrm{~h} .{ }^{*} \mathrm{p} \leq 0.05$ and $* * \mathrm{p} \leq 0.001$ were considered statistically significant (Data values are mean $\pm \mathrm{SD}, \mathrm{n}=3$ ).

A

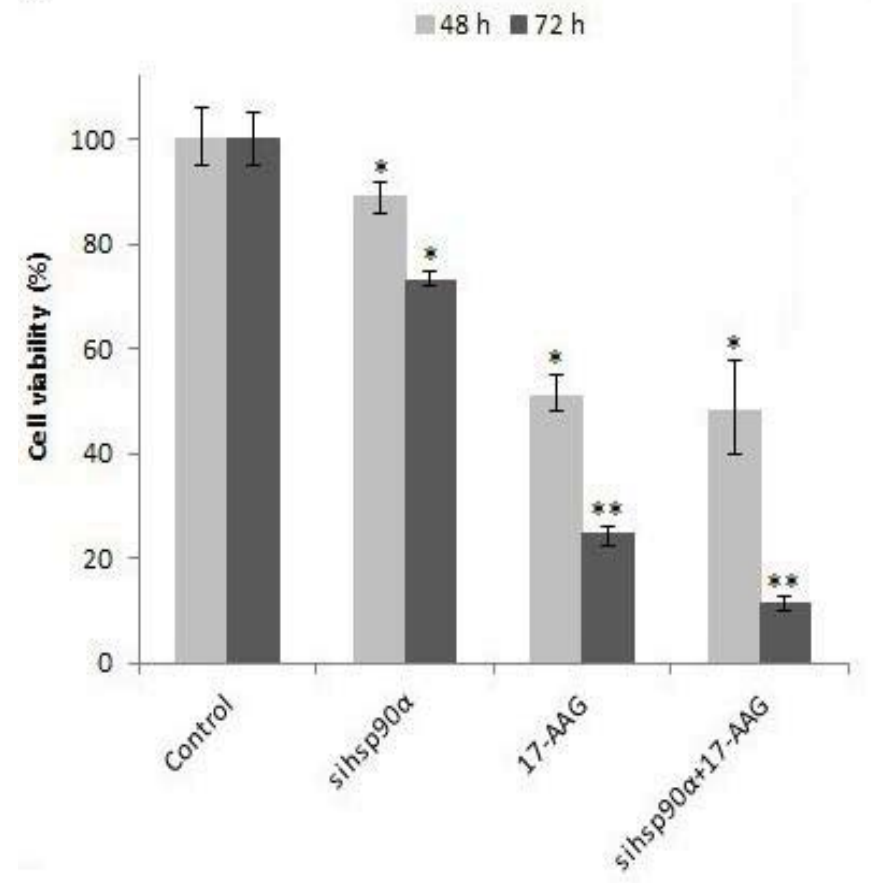

B

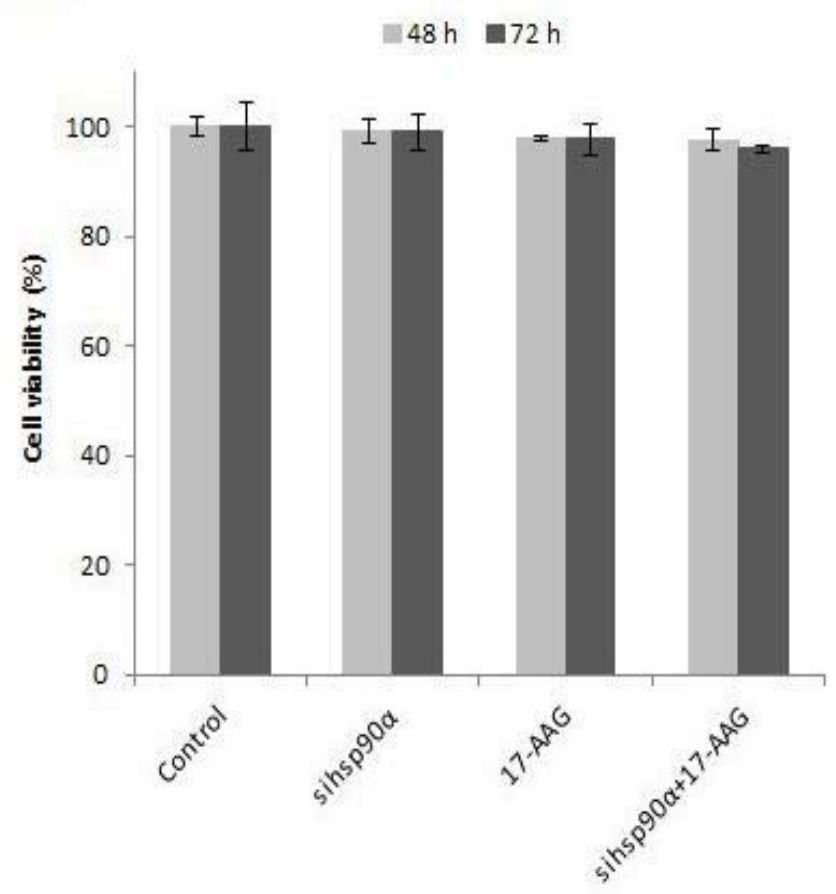

Table 1. sihsp90 $\alpha$ synergizes with $17-A A G$ enhancing chemosensitivity in U87-MG. The efficacy of the concurrent assay with $17-\mathrm{AAG}$ and sihsp90 $\alpha$ was assessed using interaction ratios generated by a ratio of the observed growth inhibition following treatment with both compounds versus growth inhibition using either compound independently. The data values are mean $\pm \mathrm{SD}, \mathrm{n}=3$.

\begin{tabular}{|l|l|l|}
\hline Interaction Ratio & sihsp90 $\boldsymbol{\alpha}$ & 17-AAG \\
\hline after $\mathbf{4 8 ~ h}$ & $4.62 \pm 1.35$ & $1.05 \pm 0.11$ \\
after $\mathbf{7 2} \mathbf{~ h}$ & $3.28 \pm 0.19$ & $1.18 \pm 0.29$ \\
\hline
\end{tabular}

\subsection{Silencing hsp $90 \alpha$ in Vitro with sihsp $90 \alpha$}

In order to assess the efficiency of silencing $h s p 90 \alpha$, U87-MG cells were treated with 17-AAG, sihsp $90 \alpha$ or combination of sihsp90 $\alpha / 17-\mathrm{AAG}$ to measure $h s p 90 \alpha$ and GAPDH mRNA expression using qRT-PCR. Cells transfected with sihsp $90 \alpha$ alone reduced the mRNA copy number by $96 \%$ after $48 \mathrm{~h}$, however, the mRNA copy number recovered to $65 \%$ after $72 \mathrm{~h}$ (Figure 2A,B). 17-AAG 
demonstrated a successful downregulation of $h s p 90 \alpha$ expression and reduced mRNA copy numbers by $92 \%$ and $90 \%$ after $48 \mathrm{~h}$ and $72 \mathrm{~h}$, respectively. A combinatorial treatment with sihsp $90 \alpha$ and $17-\mathrm{AAG}$ together silenced $h s p 90 \alpha$ by $99 \%$ after $48 \mathrm{~h}$ and $72 \mathrm{~h}$. The qRT-PCR results were also validated by agarose gel electrophoresis (Figure 2A,B). The level of $h s p 90 \alpha$ and GAPDH was also quantitated in a normal human astrocyte cell line SVGp12 to validate targeting $h s p 90 \alpha$, a therapeutic candidate in this study (Figure 3A,B). The $h s p 90 \alpha$ levels in SVGp12 demonstrated negligible though detectable levels of mRNA. The different treatments did not have any significant effect on transcriptional regulation of $h s p 90 \alpha$.

Figure 2. The effects of $17-\mathrm{AAG}$ and sihsp $90 \alpha$ on $h s p 90 \alpha$ expression. mRNA expression levels of $h s p 90 \alpha$ and GAPDH in U87-MG cells treated with Hsp90 inhibitor 17-AAG and/or sihsp $90 \alpha$ which targets exon 5 on the $h s p 90 \alpha$ gene were assessed by agarose gel electrophoresis and qRT-PCR for mRNA gene expression copy numbers after (A) $48 \mathrm{~h}$ and (B) 72 h. Lane (1) control, (2) sihsp90 $\alpha$, (3) 17-AAG, (4) sihsp90 $\alpha+17-A A G$. sihsp90 $\alpha$ represents cells treated with $h s p 90 \alpha$ specific siRNA. sihsp90 $\alpha+17-A A G$ represent concurrent assays where the cells were treated with 17-AAG and sihsp $90 \alpha$ for either $48 \mathrm{~h}$ or $72 \mathrm{~h} .{ }^{*} \mathrm{p} \leq 0.05$ was considered statistically significant (Data values are mean $\pm \mathrm{SD}, \mathrm{n}=3$ ).

A

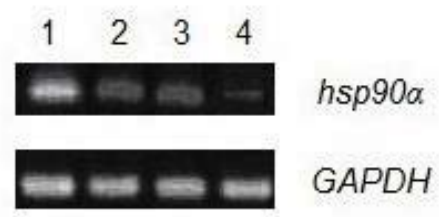

$48 \mathrm{~h}$

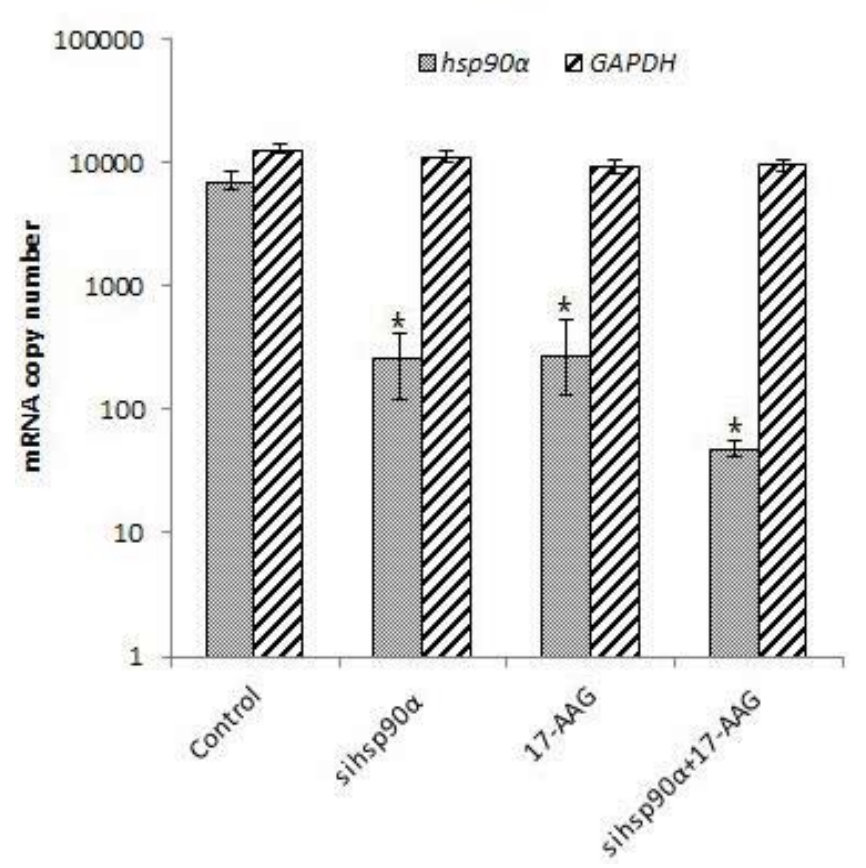

B

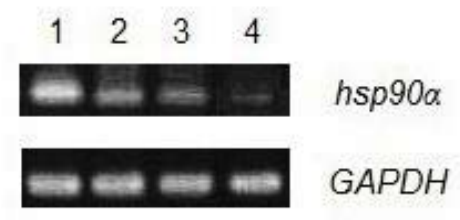

$72 \mathrm{~h}$

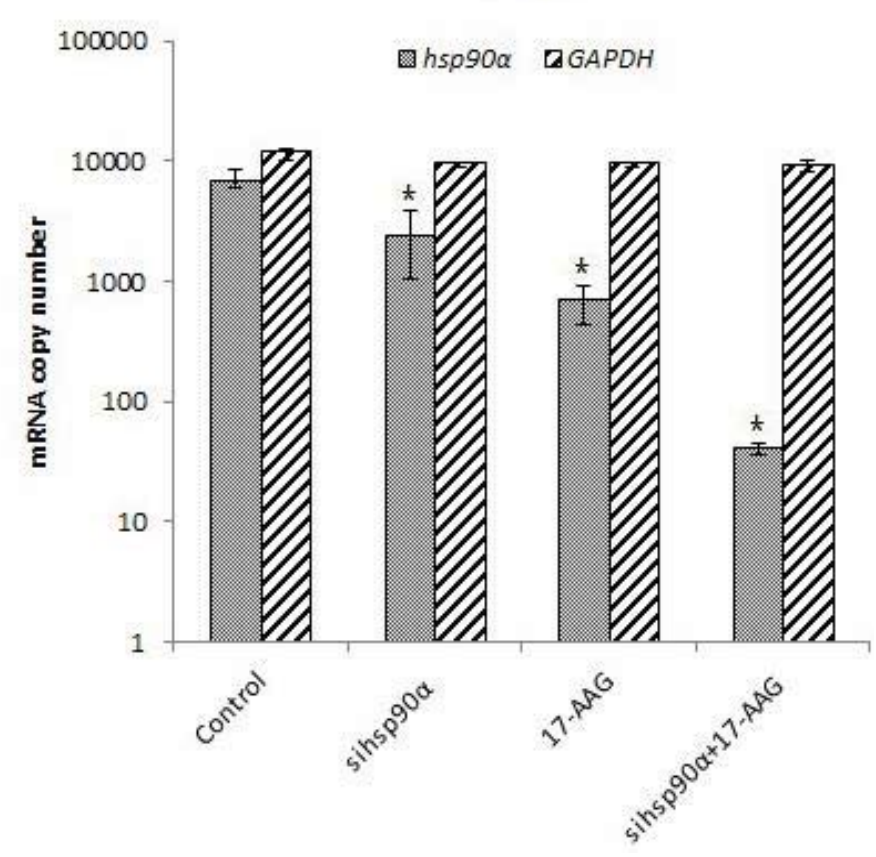


Figure 3. $h s p 90 \alpha$ transcription level in SVGp12. mRNA expression levels of $h s p 90 \alpha$ and GAPDH in SVGp12 cells treated with sihsp90 $\alpha$ which targets exon 5 on the $h s p 90 \alpha$ gene and/or Hsp90 inhibitor 17-AAG were assessed by agarose gel electrophoresis (A) and qRT-PCR (B), for mRNA gene expression copy numbers after $48 \mathrm{~h}$ and $72 \mathrm{~h}$. Lane (1)

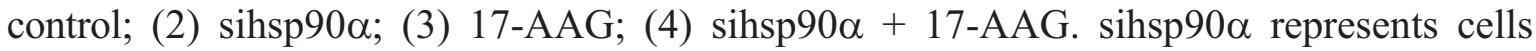
treated with $h s p 90 \alpha$ specific siRNA. sihsp $90 \alpha+17-A A G$ represent concurrent assays where the cells were treated with $17-\mathrm{AAG}$ and $\operatorname{sihsp} 90 \alpha$ for either $48 \mathrm{~h}$ or $72 \mathrm{~h}$. Data values are mean $\pm \mathrm{SD}, \mathrm{n}=3$.

A

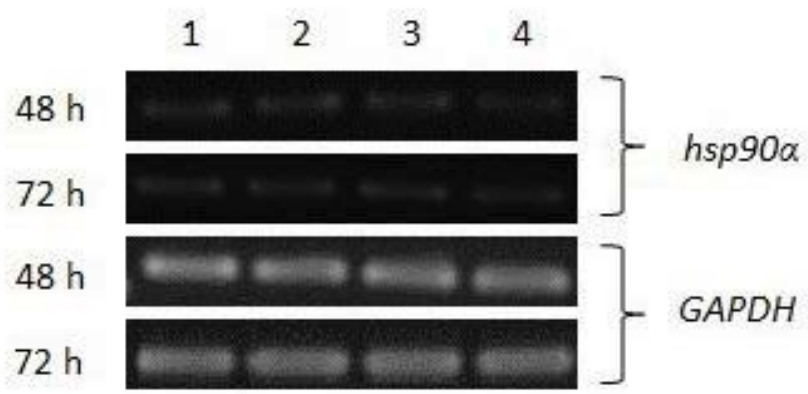

B

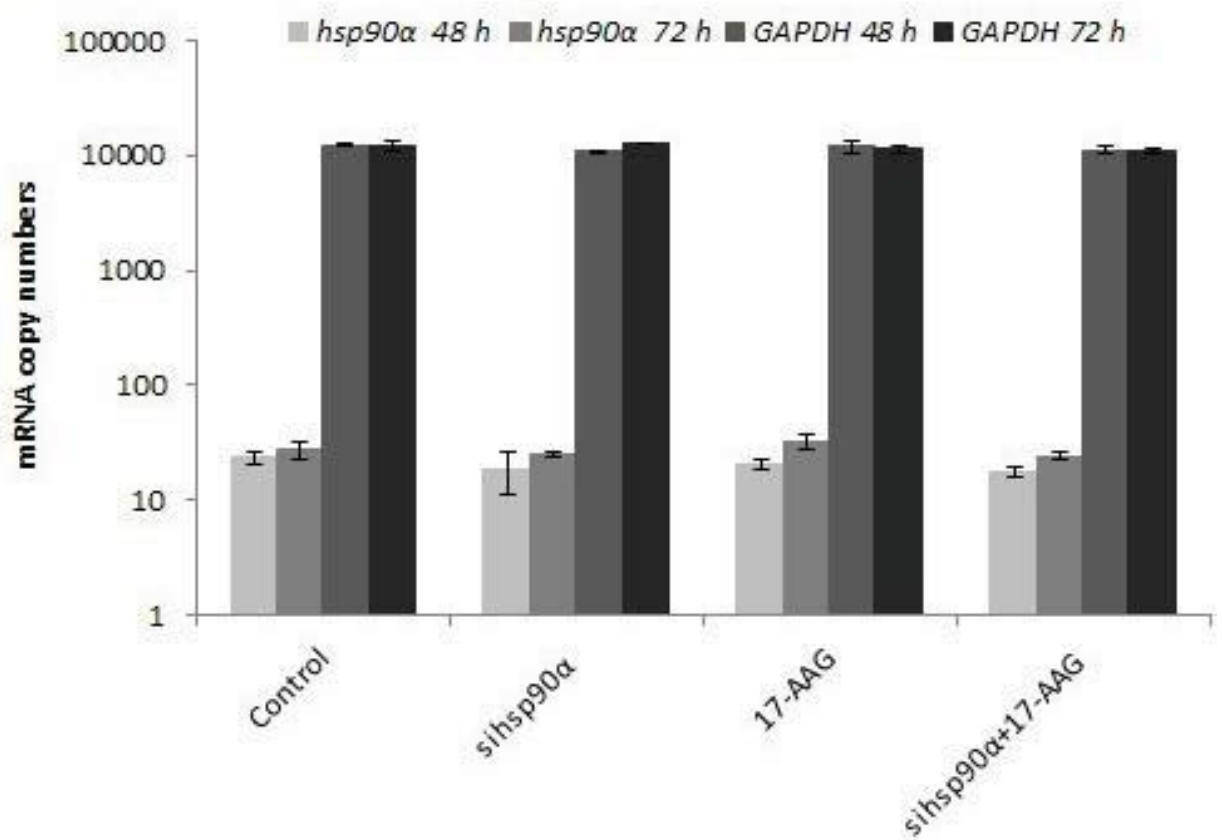

2.4. 17-AAG and sihsp90 $\alpha$ Exposure Promotes Hsp90 $\alpha$ Protein Degradation in U87-MG Cell Line

Hsp90 $\alpha$ protein levels were monitored by immunocytochemistry to correlate the transcription to the protein levels following sihsp90 $\alpha$ and 17-AAG treatment. Figure 4 represents a sample of the stained

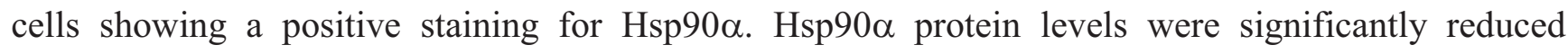
following independent treatment with 17-AAG and sihsp90 $\alpha$. Most degradation of Hsp90 $\alpha$ protein was observed after combinatorial treatment using 17-AAG and sihsp $90 \alpha$ simultaneously, whereby only $4.3 \%$ of cells expressed Hsp90 $\alpha$ after $48 \mathrm{~h}$ and $72 \mathrm{~h}$ (Table 2). When used as individual agents, sihsp $90 \alpha$ and 17 -AAG reduced Hsp90 $\alpha$ protein levels to $30.9 \%$ and $11.4 \%$, respectively. Based on the 
qRT-PCR and Hsp90 $\alpha$ protein expression data, a clear correlation between the Hsp $90 \alpha$ mRNA and protein expression levels was made.

Figure 4. Hsp90 $\alpha$ protein level in U87-MG assessed using immunohistochemistry. The cells were stained with FITC conjugate secondary antibody bound to Hsp90 $\alpha$ antigen (green) and propidium iodide (PI) to detect nucleus (red) at $\times 40$ objective magnifications. Hsp90 $\alpha$ was mainly located in the cell cytoplasm.
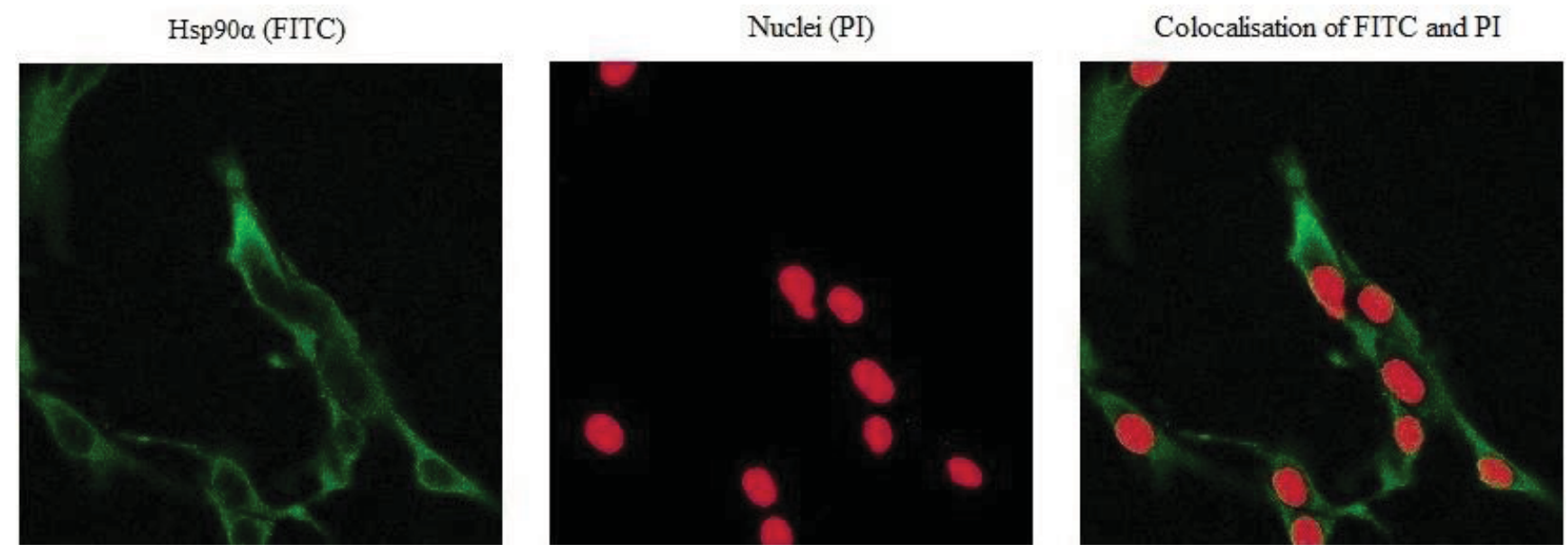

Table 2. Hsp90 $\alpha$ expression in U87-MG post $17-A A G$ and sihsp $90 \alpha$ treatment. The Hsp90 $\alpha$ levels were deduced as the fraction of the observed Hsp90 $\alpha$ levels in treated samples relative to the total Hsp90 $\alpha$ levels in the untreated sample using immunofluorescence after $48 \mathrm{~h}$ and $72 \mathrm{~h}$. Hsp90 $\alpha$ expression analysis using immunofluorescence was performed by counting 150 cells. sihsp $90 \alpha$ represent cells treated with $h s p 90 \alpha$ specific siRNA. sihsp $90 \alpha+17-\mathrm{AAG}$ represent concurrent assays where the cells were treated with $17-\mathrm{AAG}$ and sihsp $90 \alpha$ for either $48 \mathrm{~h}$ or $72 \mathrm{~h}$. This data is typical of three independent experiments. $* \mathrm{p} \leq 0.05$ and $* * \mathrm{p} \leq 0.001$ were considered statistically significant.

\begin{tabular}{|c|l|l|l|l|}
\hline \% Cells Expressing Hsp90 $\boldsymbol{\alpha}$ after & Control & sihsp90 $\boldsymbol{\alpha}$ & 17-AAG & sihsp90 $\boldsymbol{\alpha}+$ 17-AAG \\
\hline $48 \mathrm{~h}$ & $64.3 \pm 4.2$ & $30.9 \pm 2.9 * *$ & $15.6 \pm 1.4^{* *}$ & $4.7 \pm 1.0^{* *}$ \\
$72 \mathrm{~h}$ & $65.1 \pm 4.6$ & $54.5 \pm 2.7 *$ & $11.4 \pm 1.2 * *$ & $4.3 \pm 0.8 * *$ \\
\hline
\end{tabular}

\subsection{Hsp90 $\alpha$ Inhibition Promotes Degradation of Hsp90 Client Akt/PKB Kinase in U87-MG}

To examine whether Hsp90 $\alpha$ inhibition was accompanied by rapid loss of Akt protein, the Akt kinase activity was monitored in control and treated U87-MG cells using a Akt/PKB kinase activity assay. A combination of sihsp $90 \alpha$ and $17-\mathrm{AAG}$ reduced Akt activity to $47.3 \%$ and $43 \%$ after $48 \mathrm{~h}$ and $72 \mathrm{~h}$, respectively (Figure 5). When only 17-AAG was used, it was found to reduce Akt levels to $63 \%$ and $61 \%$ after $48 \mathrm{~h}$ and $72 \mathrm{~h}$ treatments. Silencing $h s p 90 \alpha$ with siRNA inactivated Akt activity by $41 \%$ after $48 \mathrm{~h}$. However, after $72 \mathrm{~h}$ the Akt activity was upregulated to over $100 \%$. The expression profile of Akt emulates that of Hsp90 $\alpha$ mRNA and the protein level following sihsp90 $\alpha$ and 17-AAG treatments (Figure 2 and Table 2). The results of the qRT-PCR, Hsp90 $\alpha$ protein and Akt activity indicates a strong correlation between mRNA, protein and Akt expression levels in U87-MG cell line (Table 3). 
Figure 5. Hsp90 $\alpha$ inhibition results in loss of Akt activity in U87-MG cell line. The Akt activity (\%) was deduced as the fraction of the observed Akt activity in treated samples relative to the total Akt activity in the untreated sample after $48 \mathrm{~h}$ (A) and $72 \mathrm{~h}$ (B). sihsp $90 \alpha$ represent cells treated with $h s p 90 \alpha$ specific siRNA. sihsp90 $\alpha+17-A A G$ represent concurrent assays where the cells were treated with sihsp90 $\alpha$ and 17-AAG for either $48 \mathrm{~h}$ or $72 \mathrm{~h} .{ }^{*} \mathrm{p} \leq 0.05$ and $* * \mathrm{p} \leq 0.001$ were considered statistically significant (Data values are mean $\pm \mathrm{SD}, \mathrm{n}=3$ ).

A

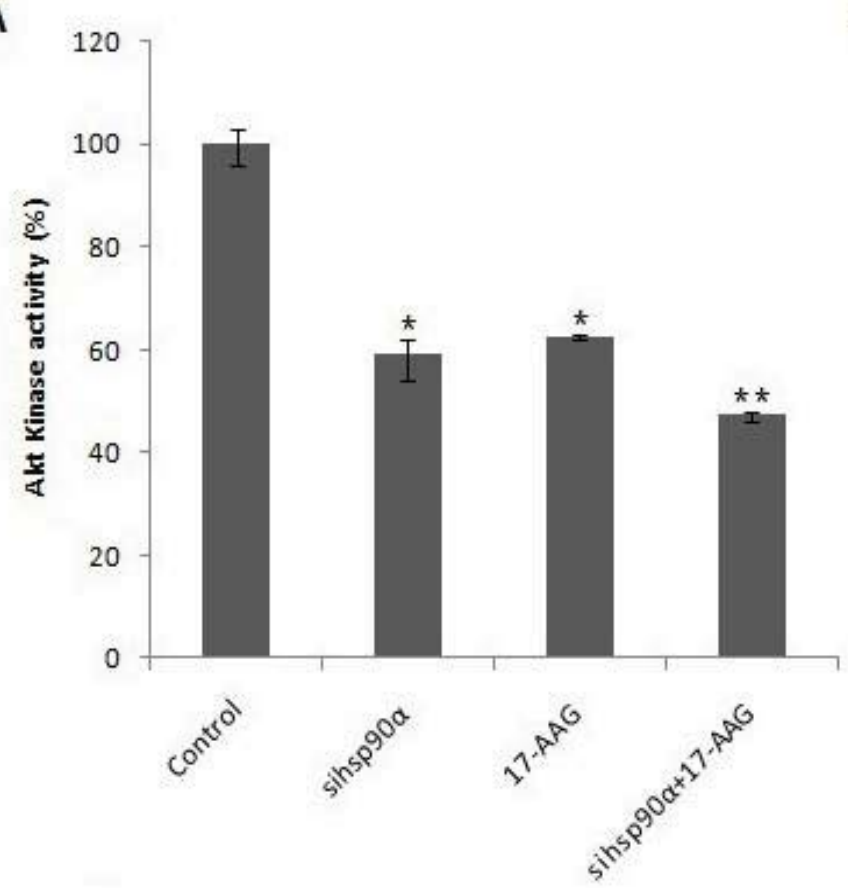

B

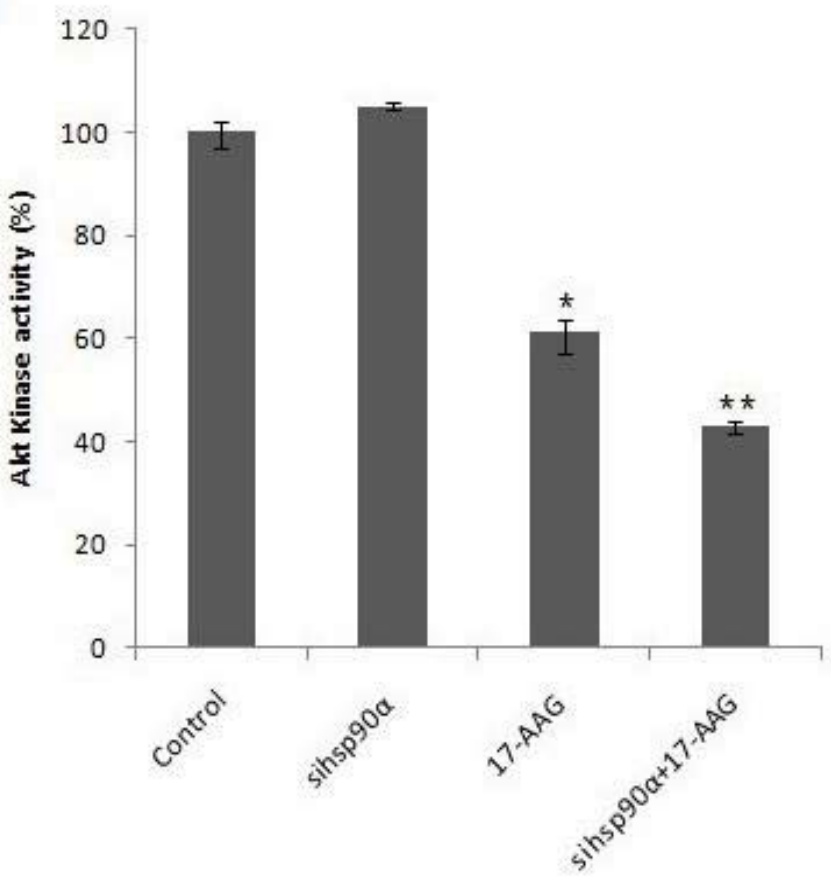

Table 3. The correlation profile between Hsp90 $\alpha$ expression at mRNA and protein with Akt activity and cell viability in U87-MG cell line.

\begin{tabular}{|c|c|c|c|c|}
\hline & $\begin{array}{l}\text { Hsp90 } \alpha \text { mRNA/100 ng } \\
\text { Cells Extract } \\
\left(1 \times 10^{6} \text { Cells }\right)\end{array}$ & $\begin{array}{l}\text { \% Cells Expressing } \\
\text { Hsp90 } \alpha\end{array}$ & $\begin{array}{l}\% \text { Akt/PKB } \\
\text { Kinase Activity }\end{array}$ & $\%$ Cell Viability \\
\hline \multicolumn{5}{|c|}{ Control } \\
\hline $48 \mathrm{~h}$ & $6,915 \pm 863$ & $64.3 \pm 4.2$ & $100 \pm 3.5$ & $100 \pm 5$ \\
\hline $72 \mathrm{~h}$ & $6,919 \pm 867$ & $65.1 \pm 4.6$ & $100 \pm 2.5$ & $100 \pm 4.5$ \\
\hline \multicolumn{5}{|c|}{ SiRNA } \\
\hline $48 \mathrm{~h}$ & $265 \pm 95$ & $30.9 \pm 2.9$ & $59.3 \pm 3.8$ & $89 \pm 3$ \\
\hline $72 \mathrm{~h}$ & $2,420 \pm 967$ & $54.5 \pm 2.7$ & $105.1 \pm 0.79$ & $73 \pm 1.5$ \\
\hline \multicolumn{5}{|c|}{ 17-AAG } \\
\hline $48 \mathrm{~h}$ & $269 \pm 107$ & $15.6 \pm 1.4$ & $62.7 \pm 0.48$ & $51 \pm 3.5$ \\
\hline $72 \mathrm{~h}$ & $694 \pm 234$ & $11.4 \pm 1.2$ & $61.1 \pm 3.4$ & $24.8 \pm 1.9$ \\
\hline \multicolumn{5}{|c|}{ siRNA/17AAG } \\
\hline $48 \mathrm{~h}$ & $48 \pm 7$ & $4.7 \pm 1.0$ & $47.3 \pm 0.91$ & $48 \pm 9$ \\
\hline $72 \mathrm{~h}$ & $40 \pm 4.5$ & $4.3 \pm 0.8$ & $43 \pm 1.28$ & $11.3 \pm 1.5$ \\
\hline
\end{tabular}




\subsection{Discussion}

In tumours, the induced Hsp90 expression is responsible for the addiction of tumour cells to multiple signalling pathways where Hsp90 clients play an oncogenic role [30]. Furthermore, the Hsp90 conformation in tumours has demonstrated a higher binding affinity for 17-AAG, compared to the native Hsp90 in normal cells [31]. Although, normal proteins have limited requirement for Hsp90 assistance, tumours are highly dependent on Hsp90 chaperone activity to cope with the lethal conditions prevalent in tumours and to regulate mutated and functionally deregulated proteins [32]. In the present study, the anti-tumour effect of 17-AAG and sihsp90 $\alpha$ in U87-MG and not SVGp12 cells validates the reliance of brain tumours on Hsp90 for tumour growth and progression. In addition, the combinatorial therapy of $17-\mathrm{AAG}$ and sihsp $90 \alpha$ may have therapeutic potential for GBM, taking into consideration, the ability of 17-AAG to target-specifically bind to tumour cells at a low concentration compared to conventional therapeutic drugs and the increasing therapeutic potential of RNAi technique for gene therapy $[28,33]$.

In order to assess quantitative gene silencing in GBM using sihsp90 $\alpha$ and 17-AAG, $h s p 90 \alpha$ and GAPDH (control) mRNA expressions were measured using qRT-PCR. Results showed that a combination of $17-\mathrm{AAG}$ and sihsp $90 \alpha$ significantly reduced $h s p 90 \alpha$ copy numbers by $99 \%$ in GBM after $48 \mathrm{~h}$ and $72 \mathrm{~h}$. Sequence specific interactions between the siRNA and target mRNA are essential for RNAi functionality, and the target site recognition relies on the molecular mechanism of RNA-RNA interactions [34]. Our data reveals a therapeutic potential of the siRNA used in this study for glioma therapy. To further support our findings, the cytotoxic effects of sihsp $90 \alpha$ and 17-AAG on a normal human astrocyte cell line SVGp12 was investigated. The SVGp12 cell viability was not significantly affected showing less than 5\% reduction in viable cells after $48 \mathrm{~h}$ and $72 \mathrm{~h}$ which clearly demonstrated selective tumour cell targeting over normal cells. These findings correlate with previous studies in our laboratory, which shows that $h s p 90 \alpha$ expression is highly induced in U87-MG, compared to normal counterpart [23]. Since $h s p 90 \alpha$ was transcribed at basal level in SVGp12 and other normal brain cell lines [23], there was no need to carry out further investigations to utilizing these cell lines.

The transcription of human $h s p 90 \alpha$ gene is regulated by the $5^{\prime}$ upstream promoter sequences bearing the heat shock elements (HSEs) known to regulate gene expression of $h s p 90 \alpha$ [19]. The heat shock factor 1 (HSF1) binds to the HSEs and marks the initiation of $h s p 90 \alpha$ gene transcription. Under normal conditions, HSF1 is bound to cytosolic Hsp90 and Hsp70 and hence avoids transcription of heat shock genes. However, under stress, or upon inhibition of Hsp90, the Hsp90 chaperone refolds partially denatured client proteins which liberates HSF1, consequently resulting in its translocation to the nucleus where it initiates transcription of $h s p 90$ gene [35]. This negative feedback mechanism may be a continued source of Hsp90 in tumour cells treated with 17-AAG or sihsp90 $\alpha$, which may be responsible for tumour survival even after $72 \mathrm{~h}$. In this study, we targeted the inducible isoform $h s p 90 \alpha$ mRNA using sihsp $90 \alpha$ and Hsp90 protein using 17-AAG with an aim to achieve maximum Hsp90 inhibition. The results from this study indicate that the enhanced synergistic cytotoxicity observed in glioblastoma U87-MG and not in normal astrocyte cell line SVGp12, using combination treatment with sihsp90a/17-AAG, may be due to a greater degree of Hsp90 inhibition. Our results also indicate that the normal astrocytes SVGp12 are not dependent on Hsp90 for cell growth and survival. 
The fundamental role of Hsp90 $\alpha$ in tumour invasion and cell cycle has previously been investigated [36]. However, altered $h s p 90 \alpha$ expression post 17-AAG treatment has not been studied in U87-MG cells. Nevertheless, a study by Clarke et al. investigating $h s p 90 \alpha$ gene expression in colon adenocarcinoma cell lines showed that the $h s p 90 \alpha$ expression in HCT116 (human colon cancer cells) following 17-AAG treatment was induced [37]. The same treatment on HT29 (human colon cancer grade II cell line) had no influence on $h s p 90 \alpha$ mRNA levels, suggesting that the post-transcriptional regulation of $h s p 90 \alpha$ after 17-AAG treatment was cell line dependent [37]. In GBM, 17-AAG was observed to downregulate $h s p 90 \alpha$ mRNA expression after $48 \mathrm{~h}$ and $72 \mathrm{~h}$ which correlates with its cytotoxic effects in vitro.

Hsp90 expression in tumours is 2 to 10 -fold higher as compared to its basal expression in normal counterparts [38]. In addition to chaperoning mutated and deregulated client proteins, Hsp90 is of critical importance in tumour survival and progression. Theoretically, silencing $h s p 90 \alpha$ gene with sihsp $90 \alpha$ should lead to tumour demise. The overall results from this study reveal non-complementarity between the cell viability and qRT-PCR data after sihsp90 $\alpha$ treatment. Although, hsp $90 \alpha$ mRNA expression was reduced by $96 \%$, the cell viability was barely affected at $90 \%$. hsp $90 \alpha$ gene silencing was effective up to $48 \mathrm{~h}$ using sihsp $90 \alpha$, however, sihsp90 $\alpha$ vulnerability to metabolism within the cell and its inability to duplicate [39], ultimately lead to $h s p 90 \alpha$ resurgence after $72 \mathrm{~h}$. In contrast, the Hsp90 protein half-life of $36 \mathrm{~h}$ may suggest that the efficacy of $h s p 90 \alpha$ silencing on cell viability was modest after $48 \mathrm{~h}$ and $72 \mathrm{~h}$, owing to the downstream regulation of anti-apoptotic clientele by Hsp90 [40].

The Hsp90 $\alpha$ expression after treatment with 17-AAG and sihsp90 $\alpha$ were measured by immunocytochemistry. The Hsp90 $\alpha$ peptide was detected using FITC-conjugated secondary antibodies, taking into consideration the intensity, contrast and sharpness of the image. The Hsp90 $\alpha$ protein expression profiles showed a distinct correlation with the $h s p 90 \alpha$ mRNA expression in U87-MG which strongly suggests that the regulation of Hsp90 occurs not only at post-translational level as proposed by previous observations [30], but also under transcriptional control.

The Hsp90 chaperone plays a vital role at maintaining Akt stability [40]. The involvement of Akt kinase in deregulated signalling pathways which facilitates tumour progression, survival and invasion, has been well documented [41]. Previous studies have demonstrated severe inhibition of Akt-dependent anti-apoptotic signalling pathways upon 17-AAG administration in gastric cancers, urinary bladder cancer and osteosarcoma [30,42,43]. To determine whether Hsp90 $\alpha$ inhibition/silencing disturbed Akt levels in U87-MG, Akt kinase activity was measured using a Akt/PKB kinase activity kit. The present study showed downregulation of Akt kinase levels post 17-AAG and sihsp90 $\alpha$ treatment which decisively contributes to the cytotoxic potencies of 17-AAG and sihsp90 $\alpha$ after $48 \mathrm{~h}$ and $72 \mathrm{~h}$. The decrease in cell viability observed in U87-MG cells may be attributed to the 17-AAG-dependent inhibition of Akt activity in addition to the sihsp90 $\alpha$-mediated $h s p 90 \alpha$ downregulation which counteracts the tumour survival response of $h s p 90 \alpha$ upregulation [22], eventually leading to Hsp90 depletion and apoptosis. It has been previously demonstrated that depletion of $h s p 90 \beta$ by siRNA can induce apoptosis in multiple myeloma [44], which may suggest cooperating anti-apoptotic properties for Hsp90 $\alpha$ and Hsp90ß. In this study, downregulation of Hsp90 $\alpha$ with sihsp90 $\alpha$ was insufficient in suppressing Akt activity in U87-MG after $72 \mathrm{~h}$, possibly due to the anti-apoptotic role of Hsp90 $\beta$ via association with Bcl-2 leading to caspase inactivation and to cell survival [45]. Also, it could be 
attributed to the inability of siRNA to duplicate, reducing silencing efficacy through cell division [39]. This may suggest why Akt levels recovered after $72 \mathrm{~h}$ following sihsp90 $\alpha$ treatment.

Although, 17-AAG and sihsp $90 \alpha$ triggered Akt degradation, interestingly, the most significant Akt suppression achieved was relatively higher than the corresponding Hsp90 $\alpha$ levels. This may suggest that crucial components of the growth and survival signalling pathways, such as the Akt kinase, are not regulated by only Hsp90 chaperone. Indeed, upregulation of Hsp70 following Hsp90 inhibition using 17-AAG has been previously reported in prostate, cervical, and human colon tumours [37,46]. Furthermore, a recent proteomic study from our laboratory also showed the induced Hsp70 levels post 17-AAG exposure in glioblastoma cells (data unpublished). Thus, even though 17-AAG and sihsp90 $\alpha$ inhibited Hsp90 $\alpha$ levels in GBM, compensatory upregulation of Hsp70 may have proven to exhibit regulatory effects on Akt [47]. The Akt activity was reduced by 2.3-fold with the dual combination treatment after $72 \mathrm{~h}$ despite the Hsp70 compensation. This reduction of Akt activity demonstrates induced chemosensitivity in GBM since Hsp90 binds and protects Akt from dephosphorylation which is responsible for inactivation of Bcl-2 family protein Bad and caspase-9, known to be inducers of the intrinsic apoptosis pathway [20].

In our investigation, we have shown for the first time that a combination of 17-AAG and siRNA targeting $h s p 90 \alpha$ significantly suppresses GBM growth after $48 \mathrm{~h}$ and $72 \mathrm{~h}$ in vitro, clearly evident from the reduced Akt activity. This suggests that mutated proteins in GBM may have enhanced Hsp90 $\alpha$ binding affinity and are more sensitive to Hsp90 $\alpha$ inhibition [23]. Despite its anti-tumour activity in GBM, RNAi efficiency using siRNA is very limited in vivo, mainly due to siRNA degradation by nucleases, non-specific immune stimulation and poor cellular uptake $[27,48,49]$. However, intracellular delivery of biologically active siRNA has been successfully achieved using delivery systems $[50,51]$. The on-going work in our laboratory aims to address these limitations and to enhance cellular siRNA uptake, serum stability and pharmacokinetics using cell penetrating peptides.

\section{Experimental Section}

\subsection{Cell Culture}

The human brain tumour cell line U87-MG (glioblastoma multiforme) and human normal astrocyte cell line SVGp12 were purchased from European Collection of Cell Cultures (ECACC) and the American Type Culture Collection (ATCC), respectively. Both U87-MG and SVGp12 were cultured in Eagle's minimum essential medium (EMEM) (Lonza). The culture medium was supplemented with 2 mM L-glutamine (Sigma), 10\% FBS (Gibco-BRL, Paisley, UK), 1\% (v/v) non-essential amino acids and $1 \mathrm{mM}$ sodium pyruvate. The cells were incubated at $37{ }^{\circ} \mathrm{C}$ in a humidified $5 \% \mathrm{CO}_{2}$ incubator.

\subsection{Drug Preparation and Treatment}

17-AAG was obtained from InvivoGen (UK) and was reconstituted in DMSO to give a stock concentration of $2 \mathrm{mM}$. The glioblastoma U87-MG was treated with increasing concentrations of 17-AAG and a $50 \%$ inhibitory concentration $\left(\mathrm{IC}_{50}\right)$ of $225 \mathrm{nM}$ was determined (Figure 6). The stock solution was diluted in culture medium to achieve a final working concentration of $225 \mathrm{nM}$ which was added to the cells and incubated for $48 \mathrm{~h}$ and/or $72 \mathrm{~h}$. 
Figure 6. The $\mathrm{IC}_{50}$ for the Hsp90 inhibitor 17-AAG was assessed by increasing concentration of 17-AAG $(0-0.5 \mu \mathrm{M})$. The data values are mean $\pm \mathrm{SD}, \mathrm{n}=3$.

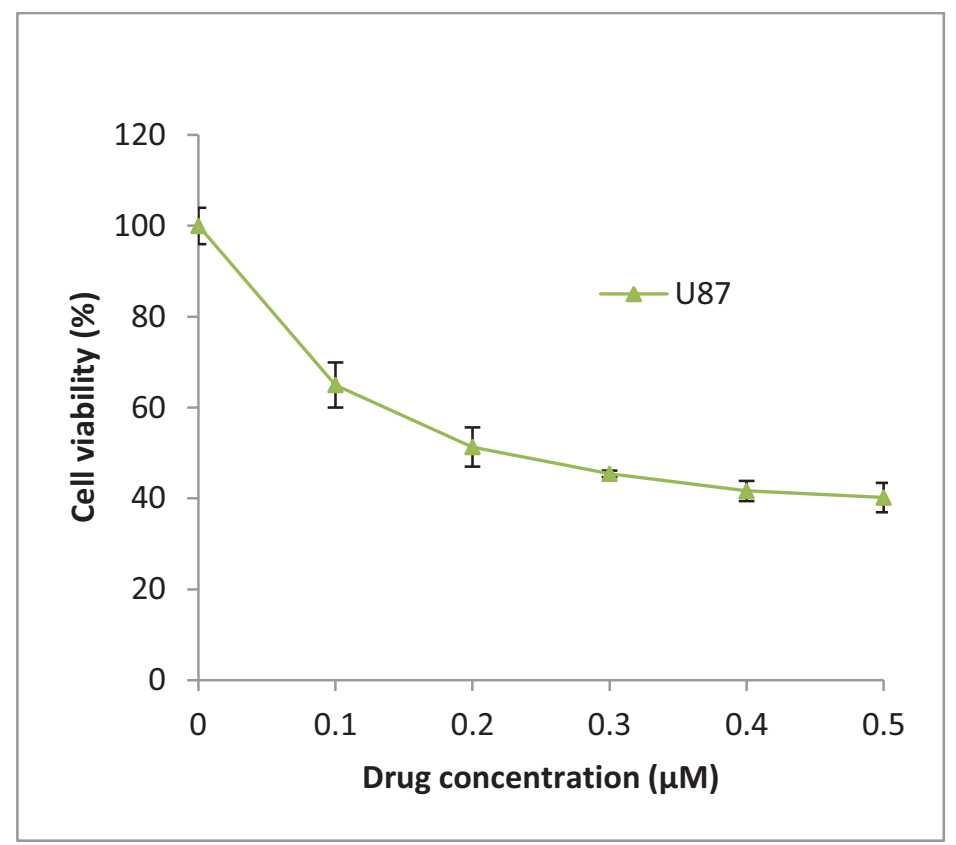

\section{3. sihsp $90 \alpha$ Electroporation and Transfection}

The Silencer ${ }^{\circledR}$ Pre-designed siRNA used for transfections were obtained from Ambion (UK). The siRNA sequences consisted of 21-nt and targets Hsp90AA1 gene with sense strand: 5' CGUGAUAAAGAAGUAAGCGtt 3' (NM_005348.3) and antisense: 5' CGCUUACUUCUUUAUCACGtt 3'. The annealed sihsp $90 \alpha$ was resuspended in nuclease-free water to achieve a stock concentration of $100 \mu \mathrm{M}$ which was further diluted to $50 \mu \mathrm{M}$ working concentration prior to use.

The electroporation condition for sihsp $90 \alpha$ used in this study has previously been optimised in our laboratory [28]. The siRNA transfections were carried out using the siPORT ${ }^{\mathrm{TM}}$ siRNA Electroporation Kit according to the manufacturer's instructions (Ambion, UK). Bio-Rad gene pulser Xcell was used for electroporation. Following transfection cells were transferred to a $25 \mathrm{~cm}^{2}$ tissue culture flask with pre-warmed medium and incubated for up to $72 \mathrm{~h}$. For concurrent combinatorial assays involving sihsp90 $\alpha$ and 17-AAG, 17-AAG $(225 \mathrm{nM})$ was added to the pre-warmed medium prior to transferring cells into the flask.

\subsection{Cell Viability Assay}

The cell viability was assessed using CellTiter-Glo ${ }^{\circledR}$ Luminescent cell viability assay (Promega, UK) [28]. Cells were seeded in a 96-well plate $24 \mathrm{~h}$ prior to treatment with sihsp90 $\alpha, 17-\mathrm{AAG}$ and/or combination of 17-AAG/sihsp90 $\alpha$. The luminescent signal was recorded using Tecan GENios Pro ${ }^{\circledR}$ (Tecan, Austria).

\section{5. $m R N A$ Isolation, Reverse Transcription and $q R T-P C R$}

An average of $1 \rho \mathrm{g} /$ cell of mRNA was extracted from cells using mRNA isolation kit (Roche Diagnostics, UK) according to manufacturer's instructions. Isolated mRNA (100 ng) was transcribed 
to cDNA using a First Strand cDNA Synthesis Kit (Roche Diagnostics, UK) which was used as a template for PCR. Quantitative Real Time PCR (qRT-PCR) was used to evaluate the expression of hsp $90 \alpha$ and GAPDH (a housekeeping gene) in control and treated U87-MG cells. Primers were obtained from TIB MOLBIOL, Germany. The primer sequence and length of the amplicons were: hsp90 $\alpha$ (189 bp) sense: 5' tctggaagatccccagacac 3', antisense: 5' agtcatccctcagccagaga 3', and GAPDH (238 bp) sense: 5' gagtcaacggatttggtcgt 3', antisense: 5' ttgattttggagggatctcg 3'. qRT-PCR was performed in triplicate using Fast Start DNA master PLUS SYBR Green 1 (Roche Diagnostics, UK) in a LightCycler real-time PCR detection system (Roche Diagnostics, Germany) as described previously [23]. Quantitative amplification was monitored by the level of fluorescence reflecting the cycle number at the detection threshold (crossing point) using a standard curve [23].

\subsection{Protein Extraction and Quantitative Assessment}

Following treatment, the cells were collected and then lysed using CelLytic ${ }^{\mathrm{TM}} \mathrm{M}$ Cell Lysis Reagent (Sigma, UK) supplemented with a protease inhibitor cocktail [52]. Total protein was isolated by centrifugation at $13,000 \mathrm{rpm}$ for $15 \mathrm{~min}$ to remove cell debris. The protein concentration was determined using the Bradford protein assay.

\subsection{Immunocytochemistry}

Cells were seeded on culture slides in 6 well plates $24 \mathrm{~h}$ prior to treatment. Following treatment the cells were fixed with $4 \%$ paraformaldehyde, washed three times with warm PBS and subsequently permeablised with $0.3 \%$ Triton X-100 at room temperature for $7 \mathrm{~min}$. The cells were washed three times with warm PBS and incubated in blocking solution followed by $1 \mathrm{~h}$ of incubating in primary monoclonal antibody against Hsp90 $\alpha$ antigen (Cambridge Bioscience, UK). After incubating the cells, they were washed and exposed to a secondary antibody (goat anti-rat IgG FITC) for $1 \mathrm{~h}$ with gentle agitation. Finally, cells were washed and counter stained with PI (Vectashield, UK), mounted and fixed on slides for analysis. For each sample, a total of 150 cells were counted using Axiovert 200M LSM 510 laser scanning confocal microscope (Carl Zeiss Ltd, UK). Hsp90 $\alpha$ was stained with FITC and the nucleus with propidium iodide (Figure 4).

\subsection{Akt/PKB Kinase Assay}

Akt/PKB kinase activity was measured using a non-radioactive Akt/PKB kinase activity assay that detects Akt/PKB kinase activity in the solution phase (Assay Designs, UK; Cat No. EKS-400A). Total protein isolated as described above and $10 \mu \mathrm{g}$ of protein from each sample were used to perform Akt kinase assay according to the manufacturer's instructions.

\subsection{Statistical Analysis}

In this study, data was analysed using the PASW Statistics 18 package using the One-Sample Students T-test and Paired-Sample T-test. A $p$ value of $* p \leq 0.05$ and $* * p \leq 0.001$ was considered as statistically significant. 


\section{Conclusions}

We have demonstrated the anti-tumour effects in GBM utilizing 17-AAG and sihsp90 $\alpha$ in vitro. The combinatorial treatment of $17-\mathrm{AAG} / \mathrm{sihsp} 90 \alpha$ significantly downregulated Hsp $90 \alpha$ mRNA and protein levels in GBM. Akt activity, a major survival kinase, was also found to be reduced. In contrast, neither of the treatments had a significant effect on SVGp12 cell viability. The transcriptional regulation of $h s p 90 \alpha$ was negligible in SVGp12. Given the role of Akt in growth signalling pathways, Hsp90-dependent Akt downregulation was accompanied by reduced cell viability. Thus, targeting Hsp90 $\alpha$ using 17-AAG/sihsp90 $\alpha$ may have a clinical prospect in treatment of GBM.

Given the role of Hsp70 and Hsp90 $\beta$ in cell survival pathways, future work could focus at downregulating Hsp70 and Hsp90 $\beta$ using protein inhibitors and siRNA respectively, and assessing its tumour inhibition potential which may enhance our understanding of the complex role played by the chaperones in tumour survival and progression.

\section{Acknowledgements}

This work was supported by a grant from the Sydney Driscoll Neuroscience Foundation (SDNF).

\section{Conflict of Interest}

The authors would like to indicate that there is no conflict of interest.

\section{References}

1. Sauvageot, C.M.E.; Weatherbee, J.L.; Kesari, S.; Winters, S.E.; Barnes, J.; Dellagatta, J.; Ramakrishna, N.R.; Stiles, C.D.; Kung, A.L. J.; Kieran, M.W.; et al. Efficacy of the HSP90 inhibitor 17-AAG in human glioma cell lines and tumorigenic glioma stem cells. Neuro-Oncology 2009, 11, 109-121.

2. Gaspar, N.; Sharp, S.Y.; Pacey, S.; Jones, C.; Walton, M.; Vassal, G.; Eccles, S.; Pearson, A.; Workman, P. Acquired resistance to 17-allylamino-17-demethoxygeldanamycin (17-AAG, tanespimycin) in glioblastoma cells. Cancer Res. 2009, 69, 1966-1975.

3. Siegelin, M.D.; Habel, A.; Gaiser, T. 17-AAG sensitized malignant glioma cells to death-receptor mediated apoptosis. Neurobiol. Dis. 2009, 33, 243-249.

4. Goetz, M.P.; Toft, D.O.; Ames, M.M.; Erlichman, C. The Hsp90 chaperone complex as a novel target for cancer therapy. Ann. Oncol. 2003, 14, 1169-1176.

5. Whitesell, L.; Lindquist, S.L. HSP90 and the chaperoning of cancer. Nat. Rev. Cancer 2005, 5, 761-772.

6. Altieri, D.C. Coupling apoptosis resistance to the cellular stress response: The IAP-Hsp90 connection in cancer. Cell Cycle 2004, 3, 255-256.

7. Bagatell, R.; Whitesell, L. Altered Hsp90 function in cancer: A unique therapeutic opportunity. Mol. Cancer Ther. 2004, 3, 1021-1030.

8. Chiosis, G.; Vilenchik, M.; Kim, J.; Solit, D. Hsp90: The vulnerable chaperone. Drug Discov. Today 2004, 9, 881-888. 
9. Jane, E.P.; Pollack, I.F. The heat shock protein antagonist 17-AAG potentiates the activity of enzastaurin against malignant human glioma cells. Cancer Lett. 2008, 268, 46-55.

10. Yu, J.Y.; DeRuiter, S.L.; Turner, D.L. RNA interference by expression of short-interfering RNAs and hairpin RNAs in mammalian cells. Proc. Natl. Acad. Sci. USA 2002, 99, 6047-6052.

11. Burger, A.M.; Fiebig, H.H.; Stinson, S.F.; Sausville, E.A. 17-(Allylamino)-17-demethoxygeldanamycin activity in human melanoma models. Anticancer Drugs 2004, 15, 377-387.

12. Yang, J.; Yang, J.M.; Iannone, M.; Shih, W.J.; Lin, Y.; Hait, W.N. Disruption of the EF-2 kinase/Hsp90 protein complex: A possible mechanism to inhibit glioblastoma by geldanamycin. Cancer Res. 2001, 61, 4010-4016.

13. Braga-Basaria, M.; Hardy, E.; Gottfried, R.; Burman, K.D.; Saji, M.; Ringel, M.D. 17-Allylamino-17-demethoxygeldanamycin activity against thyroid cancer cell lines correlates with heat shock protein 90 levels. J. Clin. Endocrinol. Metab. 2004, 89, 2982-2988.

14. Bisht, K.S.; Bradbury, C.M.; Mattson, D.; Kaushal, A.; Sowers, A.; Markovina, S.; Ortiz, K.L.; Sieck, L.K.; Isaacs, J.S.; Brechbiel, M.W.; et al. Geldanamycin and 17-allylamino-17demethoxygeldanamycin potentiate the in vitro and in vivo radiation response of cervical tumor cells via the heat shock protein 90-mediated intracellular signaling and cytotoxicity. Cancer Res. 2003, 63, 8984-8995.

15. Solit, D.B.; Zheng, F.F.; Drobnjak, M.; Munster, P.N.; Higgins, B.; Verbel, D.; Heller, G.; Tong, W.; Cordon-Cardo, C.; Agus, D.B.; et al. 17-Allylamino-17-demethoxygeldanamycin induces the degradation of androgen receptor and HER-2/neu and inhibits the growth of prostate cancer xenografts. Clin. Cancer Res. 2002, 8, 986-993.

16. Li, Y.; Zhang, T.; Schwartz, S.J.; Sun, D. New developments in Hsp90 inhibitors as anti-cancer therapeutics: Mechanisms, clinical perspective and more potential. Drug Resist. Updat. 2009, 12, $17-27$.

17. Graner, M.W.; Bigner, D.D. Chaperone proteins and brain tumors: Potential targets and possible therapeutics. Neuro-oncology 2005, 7, 260-278.

18. Porter, J.R.; Fritz, C.C.; Depew, K.M. Discovery and development of Hsp90 inhibitors: A promising pathway for cancer therapy. Curr. Opin. Chem. Biol. 2010, 14, 412-420.

19. Sreedhar, S.A.; Kalmar, E.; Csermely, P.; Shen, Y.F. Hsp90 isoforms: Functions, expression and clinical importance. FEBS Lett. 2004, 562, 11-15.

20. Lanneau, D.; de, T.A.; Maurel, S.; Didelot, C.; Garrido, C. Apoptosis versus cell differentiation: Role of heat shock proteins HSP90, HSP70 and HSP27. Prion 2007, 1, 53-60.

21. Duerfeldt, A.S.; Blagg, B.S. Hsp90 inhibition: Elimination of shock and stress. Bioorg. Med. Chem. Lett. 2010, 20, 4983-4987.

22. Chang, Y.S.; Lo, C.W.; Sun, F.C.; Chang, M.D.; Lai, Y.K. Differential expression of Hsp90 isoforms in geldanamycin-treated 9L cells. Biochem. Biophys. Res. Commun. 2006, 344, 37-44.

23. Shervington, A.; Cruickshanks, N.; Lea, R.; Roberts, G.; Dawson, T.; Shervington, L. Can the lack of HSP90 protein in brain normal tissue and cell lines, rationalise it as a possible therapeutic target for gliomas? Cancer Invest. 2008, 26, 900-904.

24. Pu, P.; Zhang, Z.; Kang, C.; Jiang, R.; Jia, Z.; Wang, G.; Jiang, H. Downregulation of Wnt2 and beta-catenin by siRNA suppresses malignant glioma cell growth. Cancer Gene Ther. 2009, 16, 351-361. 
25. Pu, P.Y.; Kang, C.S.; Zhang, Z.Y.; Liu, X.Z.; Jiang, H. Downregulation of PIK3CB by siRNA suppresses malignant glioma cell growth in vitro and in vivo. Technol. Cancer Res. Treat. 2006, 5 , 271-280.

26. Yen, M.C.; Lin, C.C.; Chen, Y.L.; Huang, S.S.; Yang, H.J.; Chang, C.P.; Lei, H.Y.; Lai, M.D. A novel cancer therapy by skin delivery of indoleamine 2,3-dioxygenase siRNA. Clin. Cancer Res. 2009, 15, 641-649.

27. Shim, M.S.; Kwon, Y.J. Efficient and targeted delivery of siRNA in vivo. FEBS J. 2010, 277, 4814-4827.

28. Cruickshanks, N.; Shervington, L.; Patel, R.; Munje, C.; Thakkar, D.; Shervington, A. Can hsp90alpha-targeted siRNA combined with TMZ be a future therapy for glioma? Cancer Invest. 2010, 28, 608-614.

29. Stommel, J.M.; Kimmelman, A.C.; Ying, H.; Nabioullin, R.; Ponugoti, A.H.; Wiedemeyer, R.; Stegh, A.H.; Bradner, J.E.; Ligon, K.L.; Brennan, C.; et al. Coactivation of receptor tyrosine kinases affects the response of tumor cells to targeted therapies. Science 2007, 318, 287-290.

30. Karkoulis, P.K.; Stravopodis, D.J.; Margaritis, L.H.; Voutsinas, G.E. 17-Allylamino-17demethoxygeldanamycin induces downregulation of critical Hsp90 protein clients and results in cell cycle arrest and apoptosis of human urinary bladder cancer cells. BMC Cancer 2010, 10, 481.

31. Kamal, A.; Thao, L.; Sensintaffar, J.; Zhang, L.; Boehm, M.F.; Fritz, L.C.; Burrows, F.J. A high-affinity conformation of Hsp90 confers tumour selectivity on Hsp90 inhibitors. Nature 2003, 425, 407-410.

32. Luo, W.; Dou, F.; Rodina, A.; Chip, S.; Kim, J.; Zhao, Q.; Moulick, K.; Aguirre, J.; Wu, N.; Greengard, P.; et al. Roles of heat-shock protein 90 in maintaining and facilitating the neurodegenerative phenotype in tauopathies. Proc. Natl. Acad. Sci. USA 2007, 104, 9511-9516.

33. Walsh, N.; Larkin, A.; Swan, N.; Conlon, K.; Dowling, P.; McDermott, R.; Clynes, M. RNAi knockdown of Hop (Hsp70/Hsp90 organising protein) decreases invasion via MMP-2 down regulation. Cancer Lett. 2011, 306, 180-189.

34. Elbashir, S.M.; Martinez, J.; Patkaniowska, A.; Lendeckel, W.; Tuschl, T. Functional anatomy of siRNAs for mediating efficient RNAi in Drosophila melanogaster embryo lysate. EMBO J. 2001, 20, 6877-6888.

35. Kamal, A.; Boehm, M.F.; Burrows, F.J. Therapeutic and diagnostic implications of Hsp90 activation. Trends Mol. Med. 2004, 10, 283-290.

36. Eustace, B.K.; Sakurai, T.; Stewart, J.K.; Yimlamai, D.; Unger, C.; Zehetmeier, C.; Lain, B.; Torella, C.; Henning, S.W.; Beste, G.; et al. Functional proteomic screens reveal an essential extracellular role for hsp90 alpha in cancer cell invasiveness. Nat. Cell Biol. 2004, 6, 507-514.

37. Clarke, P.A.; Hostein, I.; Banerji, U.; Stefano, F.D.; Maloney, A.; Walton, M.; Judson, I.; Workman, P. Gene expression profiling of human colon cancer cells following inhibition of signal transduction by 17-allylamino-17-demethoxygeldanamycin, an inhibitor of the hsp90 molecular chaperone. Oncogene 2000, 19, 4125-4133.

38. Isaacs, J.S.; Xu, W.; Neckers, L. Heat shock protein 90 as a molecular target for cancer therapeutics. Cancer Cell 2003, 3, 213-217.

39. McAnuff, M.A.; Rettig, G.R.; Rice, K.G. Potency of siRNA versus shRNA mediated knockdown in vivo. J. Pharm. Sci. 2007, 96, 2922-2930. 
40. Basso, A.D.; Solit, D.B.; Chiosis, G.; Giri, B.; Tsichlis, P.; Rosen, N. Akt forms an intracellular complex with heat shock protein 90 (Hsp90) and Cdc37 and is destabilized by inhibitors of Hsp90 function. J. Biol. Chem. 2002, 277, 39858-39866.

41. Brader, S.; Eccles, S.A. Phosphoinositide 3-kinase signalling pathways in tumor progression, invasion and angiogenesis. Tumori 2004, 90, 2-8.

42. Gazitt, Y.; Kolaparthi, V.; Moncada, K.; Thomas, C.; Freeman, J. Targeted therapy of human osteosarcoma with 17AAG or rapamycin: Characterization of induced apoptosis and inhibition of mTOR and Akt/MAPK/Wnt pathways. Int. J. Oncol. 2009, 34, 551-561.

43. Lang, S.A.; Klein, D.; Moser, C.; Gaumann, A.; Glockzin, G.; Dahlke, M.H.; Dietmaier, W.; Bolder, U.; Schlitt, H.J.; Geissler, E.K.; et al. Inhibition of heat shock protein 90 impairs epidermal growth factor-mediated signaling in gastric cancer cells and reduces tumor growth and vascularization in vivo. Mol. Cancer Ther. 2007, 6, 1123-1132.

44. Chatterjee, M.; Jain, S.; Stuhmer, T.; Andrulis, M.; Ungethum, U.; Kuban, R.J.; Lorentz, H.; Bommert, K.; Topp, M.; Kramer, D.; et al. STAT3 and MAPK signaling maintain overexpression of heat shock proteins 90alpha and beta in multiple myeloma cells, which critically contribute to tumor-cell survival. Blood 2007, 109, 720-728.

45. Cohen-Saidon, C.; Carmi, I.; Keren, A.; Razin, E. Antiapoptotic function of Bcl-2 in mast cells is dependent on its association with heat shock protein 90beta. Blood 2006, 107, 1413-1420.

46. McCollum, A.K.; Teneyck, C.J.; Sauer, B.M.; Toft, D.O.; Erlichman, C. Up-regulation of heat shock protein 27 induces resistance to 17-allylamino-demethoxygeldanamycin through a glutathione-mediated mechanism. Cancer Res. 2006, 66, 10967-10975.

47. Koren, J., III; Jinwal, U.K.; Jin, Y.; O'Leary, J.; Jones, J.R.; Johnson, A.G.; Blair, L.J.; Abisambra, J.F.; Chang, L.; Miyata, Y.; et al. Facilitating Akt clearance via manipulation of Hsp70 activity and levels. J. Biol. Chem. 2010, 285, 2498-2505.

48. Boado, R.J. RNA interference and nonviral targeted gene therapy of experimental brain cancer. NeuroRx 2005, 2, 139-150.

49. Schiffelers, R.M.; Ansari, A.; Xu, J.; Zhou, Q.; Tang, Q.; Storm, G.; Molema, G.; Lu, P.Y.; Scaria, P.V.; Woodle, M.C. Cancer siRNA therapy by tumor selective delivery with ligand-targeted sterically stabilized nanoparticle. Nucleic Acids Res. 2004, 32, e149.

50. Han, L.; Zhang, A.; Wang, H.; Pu, P.; Jiang, X.; Kang, C.; Chang, J. Tat-BMPs-PAMAM conjugates enhance therapeutic effect of small interference RNA on U251 glioma cells in vitro and in vivo. Hum. Gene Ther. 2010, 21, 417-426.

51. Kumar, P.; Wu, H.; McBride, J.L.; Jung, K.E.; Kim, M.H.; Davidson, B.L.; Lee, S.K.; Shankar, P.; Manjunath, N. Transvascular delivery of small interfering RNA to the central nervous system. Nature 2007, 448, 39-43.

52. Padmini, E.; Usha Rani, M. Seasonal influence on heat shock protein 90 [alpha] and heat shock factor 1 expression during oxidative stress in fish hepatocytes from polluted estuary. J. Exp. Mar. Biol. Ecol. 2009, 372, 1-8.

(C) 2011 by the authors; licensee MDPI, Basel, Switzerland. This article is an open access article distributed under the terms and conditions of the Creative Commons Attribution license (http://creativecommons.org/licenses/by/3.0/). 